\title{
Molecular analyses of the coat protein region of different viruses on Poaceae belonging to the Potyviridae
}

\author{
R Götz, W Huth *, E Maiss \\ Biologische Bundesanstalt für Land- und Forstwirtschaft, Institut für Biochemie und Pflanzenvirologie, Messeweg 11-12, \\ D-38104 Braunschweig, Germany
}

(Received 20 May 1995; accepted 15 July 1995)

Summary - The coat protein region of the RNA of 3 different viruses all infecting Poaceae and belonging to the family Potyviridae were analyzed. Brome streak mosaic virus (BrSMV) and Agropyron mosaic virus (AgMV) are described as mite-transmissible, while cocksfoot streak virus (CfSV) is transmissible by aphids. The coat protein is important for the transmission of Potyviridae and the degree of identity between their coat protein sequences is used to indicate a relationship within the Potyviridae. Alignments of the coat protein region of BrSMV and several other members of the Potyviridae show a homology of $47 \%$ to a mite-transmissible rymovirus, but only $23-30 \%$ to aphid-transmissible potyviruses. Alignments of CfSV and different aphid-transmissible potyviruses show about $50 \%$ homology, respectively. All these results agree with the classification of Potyviridae based on their coat protein region. Alignments of AgMV to mite-transmitted viruses show a homology of only about $25 \%$. This means either a low relationship between mitetransmitted Potyviridae or AgMV is possibly not transmissible by mites.

brome streak mosaic virus / Agropyron mosaic virus / cocksfoot streak virus / coat protein / classification of Potyviridae

Résumé - Analyse moléculaire de la région de la protéine capside de divers virus appartenant aux Potyviridae et infectant les poacées. La région de la protéine capside du RNA de 3 virus différents infectant les poacées et appartenant à la famille des Potyviridae a été analysée. Le virus de la mosaïque striée du brome (BrSMV) et le virus de la mosaïque du chiendent (AgMV) sont transmis par acariens, alors que le virus de la striure du dactyle (CfSV) est transmis par aphides. La protéine capside est importante pour la transmission des Potyviridae et le degré de similitude entre les séquences de leurs protéines capside est utilisé pour évaluer les relations entre ces virus. La comparaison des séquences des régions de la protéine capside du BrSMV révèle une homologie de 47\% avec celle d'un rymovirus transmissible par acariens, mais seulement $23-30 \%$ avec des potyvirus transmissibles par aphides. Entre le CfSV et différents potyvirus transmissibles par aphides, la comparaison révèle une homologie de 50\% environ. Tous ces résultats sont en accord avec la classification des Potyviridae basée sur la région couvrant la protéine capside. La comparaison de l'AgMV à des virus transmissibles par les acariens révèle une homologie de seulement $25 \%$. Cela signifie soit une faible parenté entre les Potyviridae transmissibles par acariens, soit que l'AgMV n'est pas transmissible par les acariens.

virus de la mosaïque striée du brome / virus de la mosaïque du chiendent / virus de la striure du dactyle / protéine capside / classification des Potyviridae

\footnotetext{
* Correspondence and reprints
} 


\section{INTRODUCTION}

The virus family Potyviridae is characterized by properties like particle morphology and vectortransmission. Based on their RNA-genome and their vectors different genera exist in the Potyviridae. The members of the genus Potyvirus are transmitted by aphids and have a singlestranded (ss) RNA-genome, while viruses that also have an ssRNA-genome but are transmissible by mites belong to the genus Rymovirus. Members of the genus Bymovirus are transmissible by fungi and have a bipartite genome.

A great deal of molecular analysis was done with Potyviridae infecting dicots but little information exists about Potyviridae infecting Poaceae, particularly mite-transmissible rymoviruses.

Two viruses, brome streak mosaic virus (BrSMV) and Agropyron mosaic virus (AgMV) are described as mite-transmissible. BrSMV is transmitted by the mite Aceria tulipae (Huth et al, 1995), while AgMV is transmissible by another mite Abaracus hystrix (Slykhuis, 1969). A third virus, cocksfoot streak virus (CfSV) is not transmissible by mites but by aphids (Catherall, 1971) and was also selected for molecular analyses and the comparison of sequence data. BrSMV was first isolated from Bromus mollis in Yugoslavia by Milicic et al $(1980,1982)$, but the distribution of the virus in Europe is not really known so far. AgMV and CfSV can infect several Poaceae and both viruses are described as widespread in Europe (Catherall, 1971; Slykhuis, 1973).

The coat protein, a funictional protein proteolytically processed from the polyprotein encoded by the potyviral RNA, is responsible for the encapsidation of the viral RNA but is also important for the transmission of the Potyviridae, for the aphid-transmissible potyviruses as well as for the mite-transmissible rymoviruses or the fungustransmissible bymoviruses. The degree of identity between their coat protein sequences indicates the relationship of different viruses of the Potyviridae (Shukla and Ward, 1988, 1989). According to this classification, viruses with a homology of more than $40 \%$ belong to one genus in the Potyviridae, while a lower homology indicates that the compared viruses belong to different genera in the Potyviridae.

\section{MATERIAL AND METHODS}

The isolates of the 3 viruses were propagated in wheat or cocksfoot after mechanical inoculation. Purification was done according to the method described by Huth et al (manuscript in preparation). Subsequently, the RNA was removed from virions by incubation for 45 min with proteinase $K$ followed by phenol extraction and precipitation (Maiss et al, 1988). The viral RNA was used as template for oligo(dT) primed cDNA synthesis using the Riboclone cDNA synthesis system (Promega). RNA was reverse-transcribed using AMV reverse transcriptase, and the dsDNA end was made blunt by T4-DNA polymerase. Subsequently, the cDNA was ligated to the Hincll cut phagemid vector pT7T3 (19U; Pharmacia) and cloned into Escherichia coli NM522 (Pharmacia). For CfSV RT-PCR was carried out using oligo(dT) and a specific oligonucleotide complementary to a conserved region of the Nlb gene. The DNA fragment generated was digested and subsequently cloned into pT7T3. The cDNA clones were selected by restriction mapping as well as by dot-blot hybridisation. The sequencing of the selected clones was conducted by the dideoxynucleotide chain termination method (Sanger et al, 1977). For sequencing mainly ssDNA templates were used, which were prepared with the helper phage M13K07 (Pharmacia). Each nucleotide was determined either by sequencing at least two independent cDNA clones or by sequencing both strands of a CDNA clone. The sequence data were assembled and analysed using the GCG program package (Deveraux et al, 1984). Nucleotide and protein sequences of BrSMV, AgMV and CfSV were analysed by DNASIS. For the comparison of protein sequences of different viruses, ALIGN was used and the phylogenetic tree was constructed using CLUSTAL with standard parameters.

\section{RESULTS}

Three cDNA clones representing the 3 ' terminal region of the genomic RNA of BrSMV including a poly(A)tail were sequenced. Two clones covered at their $5^{\prime}$ end the amino acid motif GDD, which is located in the NIb protein and is characteristic for RNA-dependent RNA polymerases. This led to the conclusion that, besides a part of the $\mathrm{NIb}$, the entire coat protein gene was also cloned and sequenced.

The clones of AgMV and CfSV, which were sequenced, also contain the a poly(A)tail as well as the amino acid motif GDD located in the Nlb protein. So the coat protein regions of all three viruses have been cloned and fully sequenced.

For a comparison with other members of the Potyviridae, amino acid sequences were selected for all 3 viruses, which start at the putative cleavage site between N/b and CP and cover the entire coat protein up to the $3^{\prime}$ end of the coat protein gene.

The amino acid sequence of the coat protein regions of the 3 investigated viruses were com- 
pared with the similar protein regions of several Potyviridae such as the mite-transmitted wheat streak mosaic virus (WSMV; Niblett et al, 1991) or the aphid-transmitted plum pox virus (PPV; Maiss et al, 1989), potato virus Y (PVY; Robaglia et al, 1989) and tobacco etch virus (TEV; Allison et al, 1986). These results are shown in table I. Alignments of the deduced amino acid sequence of the putative coat protein regions of BrSMV, AgMV and CfSV with those of other Potyviridae show different degrees of identity correlated with vector-transmissibility.

The alignment of the coat protein regions of BrSMV and WSMV shows a homology of $47 \%$. This suggests a close relationship between these 2 viruses, which are both transmissible by mites. The homology of BrSMV to the different aphidtransmissible potyviruses is quite smaller. Only a limited homology of 23 to $30 \%$ was observed. Alignments of the coat protein regions of CfSV and different aphid-transmissible potyviruses show about $50 \%$ homology, respectively.

The alignments of AgMV to the other Potyviridae show a homology of about $40 \%$ to aphid-transmitted viruses. In contrast, to mitetransmitted viruses a homology of only about $25 \%$ is observed.

\section{DISCUSSION}

The genome of potyviruses is a positive-sense ssRNA. In contrast to potyviruses, bymoviruses have a bipartite genome. Rymoviruses have a ssRNA genome like potyviruses. BrSMV is the first rymovirus for which a complete nucleotide sequence has been reported, and the sequence data indicate a genome organization similar to that of potyviruses (Götz and Maiss, 1995).

Table I. Percentage amino acid sequence identity of the predicted coat protein of BrSMV, AgMV and CfSV and other members of the Potyviridae including the mite-transmitted WSMV and several aphid-transmitted potyviruses.

$\begin{array}{lccc} & \text { BrSMV } & \text { AgMV } & \text { CfSV } \\ \text { BrSMV } & & & \\ \text { AgMV } & 25.7 & & \\ \text { CfSV } & 23.2 & 40.8 & \\ \text { WSMV } & 47.1 & 23.9 & 24.8 \\ \text { PPV } & 23.7 & 41.8 & 47.2 \\ \text { PVY } & 26.2 & 46.3 & 50.0 \\ \text { TEV } & 29.2 & 48.5 & 49.6\end{array}$

The results of the alignments agree with the classification based on the coat protein region. Shukla and Ward (1988) described 38-75\% identity between different aphid-transmitted potyviruses. The sequence comparison of the aphid-transmitted CfSV to other potyviruses fits into this range. The homology of BrSMV and WSMV to the aphid-transmitted potyviruses is considerably lower suggesting that they do not belong to the same genus. However, the degree of identity of $47 \%$ between BrSMV and WSMV indicates both viruses as members of one genus, the rymoviruses, which includes viruses transmissible by mites. In addition, a close relationship between these 2 viruses is not surprising, because they are transmissible not only by mites but by the same mite species Aceria tulipae (Slykhuis, 1955; Huth et al, 1995).

The degree of relationship between different members of the Potyviridae is also shown in the phylogenetic tree (fig 1). The different potyviruses have different degrees of relationship, but they are more closely related to each other than to AgMV, BrSMV or WSMV, respectively. On the other hand, BrSMV is more similar to WSMV than to any other potyvirus. The dendrogram suggests 2 groups of viruses. In the first group all of the viruses are transmissible by aphids belonging to the genus potyvirus. BrSMV and WSMV belong to another group, representing the mite-transmissible rymoviruses. In contrast, AgMV hardly fits into this group.

The described vector transmissibility of AgMV does not agree with the alignment of Potyviridae based on coat protein sequence data. This leads to the conclusion that either a low relationship exists between mite-transmitted Potyviridae transmissible by different species of mites or that AgMV is possibly not transmissible by mites.

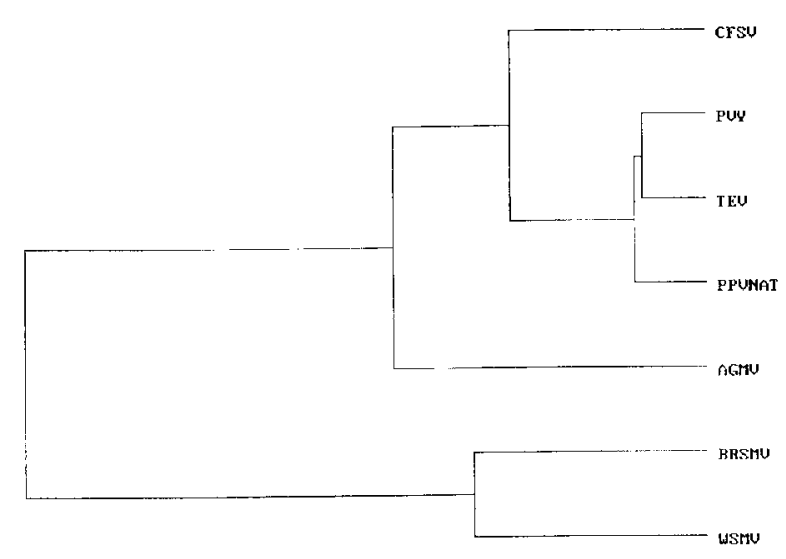

Fig 1. Phylogenetic tree. Relationship of members of the Potyviridae based on their coat protein amino acid sequence (BrSMV, AgMV, CfSV, WSMV, PPV, PVY and TEV). 


\section{ACKNOWLEDGMENTS}

We thank $P$ Bauer for excellent technical assistance. RG was granted by the Deutsche Forschungsgemeinschaft (No Go 601/1-1).

\section{REFERENCES}

Allison R, Johnston RE, Dougherty WG (1986) The nucleotide sequence of the coding region of tobacco etch virus genomic RNA: evidence for the synthesis of a single polyprotein. Virology 154, 9-20

Catherall PL (1971) Cocksfoot streak virus. CMI/AAB Descriptions of Plant Viruses, No 59, $4 p$

Deveraux J, Haeberli P, Smithies O (1984) A comprehensive set of sequence analysis programs for the VAX. NuCl Acids Res 12, 387-395

Götz R, Maiss E (1995) The complete nucleotide sequence and genome organization of the mitetransmitted brome streak mosaic rymovirus (BrSMV) in comparison to those of potyviruses. $J$ Gen Virol 76, 2035-2042

Huth W, Lesemann DE, Götz R et al (1995) Brome streak mosaic virus isolated from barley in southern France. agronomie 15, 510

Maiss E, Breyel E, Brisske A, Casper R (1988) Molecular cloning of DNA complementary to the RNA-genome of plum pox virus (PPV). $J$ Phytopathol 122, 222-231

Maiss E, Timpe U, Brisske A et al (1989) The complete nucleotide sequence of plum pox virus RNA. $J$ Gen Virol 70, 513-524
Milicic D, Kujundzic M, Wrischer M, Plavsic B (1980) A potyvirus isolated from Bromus mollis. Acta Bot Croat 39, 27-32

Milicic D, Mamula D, Plazibat M (1982) Some properties of brome streak mosaic virus. Acta Bot Croat $41,7-12$

Niblett CL, Zagula KR, Calvert LA et al (1991) CDNA cloning and nucleotide sequence of the wheat streak mosaic capsid protein gene. J Gen Virol 72, 499-504

Robaglia C, Durand-Tardif M, Tronchet M, Boudazin G, Astier-Manifacier S, Casse-Delbart F (1989) Nucleotide sequence of potato virus $Y$ ( $N$ strain) genomic RNA. J Gen Virol 70, 935-947

Sanger F, Nicklen S, Coulson AR (1977) DNA sequencing with chain-terminating inhibitors. Proc Nat Acad Sci USA 74, 5463-5467

Shukla DD, Ward CW (1988) Amino acid sequence homology of coat proteins as a basis for identification and classification of the potyvirus group. $J$ Gen Virol 69, 2703-2710

Shukla DD, Ward CW (1989) Identification and classification of potyviruses on the basis of coat protein sequence data and serology. Arch Virol 106, 171200

Slykhuis JT (1955) Aceria tulipae (agarina: eriophyidae) in relation to the spread of wheat streak mosaic. Phytopathology 45, 116-128

Slykhuis JT (1969) Transmission of Agropyron mosaic virus by the eriophyid mite, Abaracus hystrix. Phytopathology 59, 29-32

Slykhuis JT (1973) Agropyron mosaic virus. CMI/AAB Descriptions of Plant Viruses, No 118, $4 p$ 